\title{
Article
}

\section{In Situ DRIFTS-MS Methanol Adsorption Study onto Supported NiSn Nanoparticles: Mechanistic Implications in Methanol Steam Reforming}

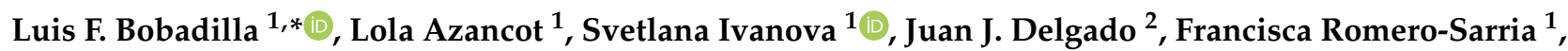 \\ Miguel A. Centeno ${ }^{1}{ }^{(\mathbb{B}}$, Anne-Cécile Roger ${ }^{3}(\mathbb{1})$ and José A. Odriozola ${ }^{1,4}$ \\ 1 Departamento de Química Inorgánica e Instituto de Ciencia de Materiales de Sevilla, \\ Centro Mixto CSIC-Universidad de Sevilla, 49 Américo Vespucio, 41092 Sevilla, Spain; \\ lola.azancot@icmse.csic.es (L.A.); sivanova@us.es (S.I.); francisca@us.es (F.R.-S.); \\ centeno@icmse.csic.es (M.A.C.); odrio@us.es (J.A.O.) \\ 2 Departamento de Ciencia de los Materiales e Ingeniería Metalúrgica y Química Inorgánica, \\ Facultad de Ciencias, Universidad de Cádiz, Campus Río San Pedro, 11510 Puerto Real (Cádiz), Spain; \\ juanjose.delgado@uca.es \\ 3 Institut de Chimie et Procédés pour l'Energie, l'Environnement et la Santé, ICPEES-ECPM, UMR CNRS 7515, \\ Université de Strasbourg, 25 Rue Becquerel, 67807 Strasbourg, France; annececile.roger@unistra.fr \\ 4 Department of Chemical and Process Engineering, University of Surrey, Guildford GU2 7XH, UK \\ * Correspondence: bobadilla@icmse.csic.es
}

Citation: Bobadilla, L.F.; Azancot, L.; Ivanova, S.; Delgado, J.J.; Romero-Sarria, F.; Centeno, M.A.; Roger, A.-C.; Odriozola, J.A. In Situ DRIFTS-MS Methanol Adsorption Study onto Supported NiSn Nanoparticles: Mechanistic Implications in Methanol Steam Reforming. Nanomaterials 2021, 11, 3234. https://doi.org/10.3390/ nano11123234

Academic Editor: Simon Freakley

Received: 9 November 2021

Accepted: 24 November 2021

Published: 28 November 2021

Publisher's Note: MDPI stays neutral with regard to jurisdictional claims in published maps and institutional affiliations.

Copyright: (c) 2021 by the authors. Licensee MDPI, Basel, Switzerland. This article is an open access article distributed under the terms and conditions of the Creative Commons Attribution (CC BY) license (https:/ / creativecommons.org/licenses/by/ $4.0 /)$.

\begin{abstract}
Methanol adsorption over both supported NiSn Nps and analogous NiSn catalyst prepared by impregnation was studied by in situ diffuse reflectance infrared Fourier transform spectroscopy (DRIFTS) to gain insights into the basis of hydrogen production from methanol steam reforming. Different intermediate species such as methoxides with different geometry (bridge and monodentate) and formate species were identified after methanol adsorption and thermal desorption. It is proposed that these species are the most involved in the methanol steam reforming reaction and the major presence of metal-support interface sites in supported NiSn Nps leads to higher production of hydrogen. On the basis of these results, a plausible reaction mechanism was elucidated through the correlation between the thermal stability of these species and the evolution of the effluent gas released. In addition, it was demonstrated that DME is a secondary product generated by condensation of methoxides over the acid sites of alumina support in an acid-catalyzed reaction.
\end{abstract}

Keywords: NiSn nanoparticles; methanol steam reforming; mechanism; in situ DRIFTS-MS

\section{Introduction}

With the depletion of fossil fuels and the growing global energy demand, as well as the Paris agreement achieved in the 21st Conference of Parties in 2015, to reduce the emission of greenhouse gases, it becomes essential to substitute the traditional energy and transport sectors based on crude oil, natural gas and coal by green fuels and low-carbon energy systems [1].

Hydrogen represents a versatile energy vector for deep decarbonization that has attracted great interest due to potential applications on proton-exchange membrane fuel cells (PEMFC's). Hydrogen can be produced from renewable sources such as biomass, wastes and water. Although novel technologies based on photocatalytic processes are emerging [2,3], hydrogen is still mainly generated by thermal processes. Due to its high energy density, low price and easy transportation, a growing interest in methanol as a fuel for hydrogen production has been concerned in the past two decades [4]. Hydrogen is essentially produced by methanol steam reforming according to Equation (1). This 
overall reaction is accompanied by other side reactions such as methanol decomposition (Equation (2)) and water gas-shift reaction (Equation (3)), as follows [5]:

$$
\begin{gathered}
\text { Methanol steam reforming: } \mathrm{CH}_{3} \mathrm{OH}+\mathrm{H}_{2} \mathrm{O} \leftrightarrow \mathrm{CO}_{2}+3 \mathrm{H}_{2} \quad \Delta \mathrm{H}_{0}=+49.7 \mathrm{~kJ} \mathrm{~mol}^{-1} \\
\text { Methanol decomposition: } \mathrm{CH}_{3} \mathrm{OH} \leftrightarrow \mathrm{CO}+2 \mathrm{H}_{2} \quad \Delta \mathrm{H}_{0}=+92.0 \mathrm{~kJ} \mathrm{~mol}^{-1} \\
\text { Water gas-shift reaction: } \mathrm{CO}+\mathrm{H}_{2} \mathrm{O} \leftrightarrow \mathrm{CO}_{2}+\mathrm{H}_{2} \quad \Delta \mathrm{H}_{0}=-41.2 \mathrm{~kJ} \mathrm{~mol}^{-1}
\end{gathered}
$$

Traditionally, $\mathrm{Cu}$-based catalysts have been the most common ones used for methanol steam reforming due to their high activity and low cost [6]. The performance of $\mathrm{Cu}$-based catalysts depends on the copper exposed area and the metallic dispersion, and thus the preparation method directly affects the catalytic activity and the properties of the $\mathrm{Cu}$ catalysts [7-9]. Furthermore, numerous studies have demonstrated that the addition of promoters such as Zn or Mn decrease the particle size of copper and enhance notably the catalytic performance of $\mathrm{Cu}$-based catalysts [10-12]. For instance, Dasireddy et al. [13] reported recently an interesting study based on $\mathrm{Cu}-\mathrm{Mn}-\mathrm{O}$ systems that present a high time-on-stream conversion of methanol under reforming conditions. Due to their low-cost, these materials are very attractive for renewable hydrogen production technology to the commercial levels. Moreover, indium is demonstrated to be an effective promoter in $\mathrm{Cu}$ based catalysts for $\mathrm{H}_{2}$ production in steam reforming of methanol [14]. However, $\mathrm{Cu}$-based catalysts are known for their pyrophoric properties and the deactivation caused by the facility of $\mathrm{Cu}$ nanoparticles to agglomerate during the reaction process, which motivates the exploration for other kinds of catalysts.

Bimetallic- and intermetallic-based catalysts have proven to be efficient in terms of stability and hydrogen productivity for methanol steam reforming due to the cooperative effect between both metals. For instance, bimetallic PtNi catalysts are reported to achieve a good level of methanol conversion and high stability [15]. Several authors have demonstrated also that PdZn catalysts became highly active and selective for the reforming of methanol and it were attributed to the formation of $\mathrm{PdZn}$ alloys [16,17]. In a previous work, we have reported a catalyst based on supported NiSn nanoparticles (NPs) that is highly stable and active for the methanol steam reforming reaction [18]. We stated that the formation of surface alloys and the number of active sites exposed seems to be determinant for the optimal performance of this bimetallic systems.

In the last three decades, the most recent advances in catalysis science were essentially addressed in the study of nanocatalysis and in situ-operando characterization to precisely correlate the structure-reactivity relationship at the atomic or nanometer level [19]. Metal nanoparticles are defined by a highly reduced size in the range of 1-10 nm, and their geometric and electronic properties are intimately related to their catalytic performance. Inspired by our previous work [18], we have prepared a catalyst based on NiSn nanoparticles dispersed on alumina as support and we have compared the catalytic performance in methanol steam reforming with other analogous catalysts prepared by co-impregnation. In order to identify the active species and relate their formation with the surface catalyst properties as well as to obtain useful information for the preparation of more effective catalysts, we have performed an in situ diffuse reflectance infrared Fourier transform spectroscopy coupled to mass spectrometry (DRIFTS-MS) study of methanol adsorption under reaction conditions. Previous studies have demonstrated that DRIFTS is a powerful tool for monitoring catalytic surface chemistry before, during, and after adsorbate introduction [20]. This work provides information insights into the interaction of methanol with the surface of the catalyst and allows the elucidation of the reaction mechanism following the involved species during the reaction.

\section{Materials and Methods}

\subsection{Chemical Reagents}

Nickel (II) nitrate hexahydrate $\left(\mathrm{Ni}\left(\mathrm{NO}_{3}\right)_{2} \cdot 6 \mathrm{H}_{2} \mathrm{O}\right.$, Panreac $\left.99 \%\right)$, nickel acetate tetrahydrate $\left(\mathrm{Ni}\left(\mathrm{CH}_{3} \mathrm{COO}\right)_{2} \cdot 4 \mathrm{H}_{2} \mathrm{O}\right.$, Fluka 99\%), anhydrous tin chloride $\left(\mathrm{SnCl}_{2}\right.$, Fluka 97\%), 
ethylenglycol (Panreac 99\%), polyvinylpyrrolidone with an average molecular weight of 10,000 (PVP, Sigma-Aldrich 100\%), sodium borohydride (Sigma-Aldrich 99\%), acetone (Sigma-Aldrich 99\%) and ethanol (Panreac 99\%) were used as raw materials. Alumina powder $\left(\gamma-\mathrm{Al}_{2} \mathrm{O}_{3}\right)$ used as support was obtained by the crushing of alumina spheres (Sasol, $1.78 \mathrm{~mm}$ diameter) in an agate mortar.

\subsection{Catalysts Synthesis}

NiSn NPs were prepared by the polyol method using polyvinylpyrrolidone (PVP) as a protector agent as described elsewhere [21]. In a typical synthesis, the appropriate amounts of $\mathrm{Ni}\left(\mathrm{CH}_{3} \mathrm{COO}\right)_{2} \cdot 4 \mathrm{H}_{2} \mathrm{O}$ and $\mathrm{SnCl}_{2}$ precursor salts to achieve an atomic ratio $\mathrm{Ni} / \mathrm{Sn}=3$ were dissolved in $70 \mathrm{~mL}$ of ethylenglycol (EG). Then, $0.7 \mathrm{~g}$ of PVP was added to the solution and heated to $50^{\circ} \mathrm{C}$ while stirring until the formation of a completely homogenous solution. Afterwards, $0.34 \mathrm{~g}$ of $\mathrm{NaBH}_{4}$ was rapidly introduced for the reduction of the metallic salts. The obtained particles were refluxed at $200^{\circ} \mathrm{C}$ for $3 \mathrm{~h}$ in order to assure the formation of $\mathrm{Ni}-\mathrm{Sn}$ intermetallic compound. The black colloidal solution formed was then cooled down to room temperature and mixed with the appropriate amount of alumina in order to obtain $10 \mathrm{wt} . \%$ of NiSn nanoparticles supported over alumina. A small portion of the colloidal suspension was separated for HRTEM analysis. The solid was collected by centrifugation, washed several times with acetone and ethanol, and dried at $100{ }^{\circ} \mathrm{C}$ overnight. Finally, the sample was calcined at mild temperature of $350{ }^{\circ} \mathrm{C}$ for $1 \mathrm{~h}$ in order to remove the rest of PVP surrounding the nanoparticles. The obtained catalyst was labelled as NiSn-NPs.

Analogously, a similar catalyst was prepared by impregnation using $\mathrm{Ni}\left(\mathrm{NO}_{3}\right)_{2}$ and $\mathrm{SnCl}_{2}$ as precursor salts in the adequate amount to achieve an atomic ratio Ni/Sn of 3 and total loadings of $10 \mathrm{wt} . \%$. In this case, the sample was calcined at $750{ }^{\circ} \mathrm{C}$ for $1 \mathrm{~h}$ and the catalyst obtained was designated as NiSn-IMP. The different calcination temperature selected in both catalysts is based on the TPR results as will be discussed below.

\subsection{Characterization Methods}

High-resolution transmission electron (HRTEM) micrographs were recorded on a $200 \mathrm{kV}$ JEOL JEM-2010F instrument with a structural resolution of $0.19 \mathrm{~nm}$ at Scherzer defocus conditions. Scanning transmission electron microscopy (STEM) images were collected in the same instrument using a high-angle annular dark-field (HAADF) detector and an electron-beam probe of $0.5 \mathrm{~nm}$ to determine the particle size distribution.

In order to determine the crystalline structure of the prepared samples before and after reduction, X-ray diffraction (XRD) analysis was performed in a Siemens D500 diffractometer. Diffraction patterns were recorded using $\mathrm{Cu} K_{\alpha}$ radiation $(40 \mathrm{~mA}, 40 \mathrm{kV})$ and a position-sensitive detector using a step size of $0.05^{\circ}$ and a step time of $1 \mathrm{~s}$.

Thermogravimetric analysis (TGA) was carried out on SDTQ60 thermobalance from 30 to $1200{ }^{\circ} \mathrm{C}$ with a heating rate of $2{ }^{\circ} \mathrm{C} \mathrm{min}-1$ by passing constant air flow of $50 \mathrm{~mL} \mathrm{~min}^{-1}$.

Temperature-programmed reduction (TPR) measurements were performed to study the reducibility of the prepared catalysts. The analyses were performed on $50 \mathrm{mg}$ of fresh catalyst under $50 \mathrm{~mL} \mathrm{~min}^{-1}$ of a calibrated mixture of $3.85 \% \mathrm{H}_{2}$ in Ar. The temperature was increased from room temperature up to $1000{ }^{\circ} \mathrm{C}$ at $15^{\circ} \mathrm{C} \mathrm{min}^{-1}$, and the $\mathrm{H}_{2}$ consumption was monitored by the TCD detector.

\subsection{Catalytic Activity Tests}

The methanol steam reforming catalytic tests were performed in a quartz fixed-bed reactor at atmospheric pressure. Prior to the reaction, the catalyst prepared by impregnation was reduced in situ at $800{ }^{\circ} \mathrm{C}$ for $1 \mathrm{~h}$ in $3 \mathrm{NmL} \mathrm{min}{ }^{-1}$ of reductant flow $(5 \% \mathrm{v} / \mathrm{v}$ $\mathrm{H}_{2}$ :Ar). Then, the hydrogen flow was substituted by an $4 \mathrm{Ar}: 1 \mathrm{~N}_{2}$ mixture with a total flow

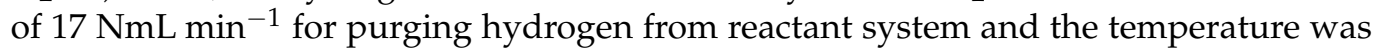
decreased to the reaction one $\left(350^{\circ} \mathrm{C}\right)$. The pretreatment procedure for NiSn-NPs catalyst is identical but in this case the reduction temperature was $350{ }^{\circ} \mathrm{C}$. After reduction pretreatment, the methanol-water mixture $\left(1 / 2\right.$ molar ratio and $0.7 \mathrm{NL} \mathrm{h}^{-1}$ of mixture in gas 
phase) was added to the $4 \mathrm{Ar}: 1 \mathrm{~N}_{2}$ mixture entering the reactor. In all the experiments, the gas hourly space velocity (GHSV, STP conditions) was $26,000 \mathrm{~h}^{-1}$. The effluent stream was analyzed online using a gas micro-chromatograph equipped with two columns (Poraplot $\mathrm{Q}$ and molecular sieve $5 \AA$ ) and TCD detectors. The $\mathrm{N}_{2}$ in the stream feed inlet was used as internal standard. It should be mentioned that empty reactor and loaded with pure alumina showed no activity under these reaction conditions.

\subsection{In Situ Drifts Measurements}

In situ methanol adsorption studies followed by IR spectroscopy was performed using a high-temperature controlled DRIFT chamber from Spectra-Tech 101 with ZnSe windows coupled to a Thermo Nicolet Nexus infrared spectrometer using KBr optics and a $\mathrm{MCT} / \mathrm{B}$ detector working at liquid nitrogen temperature. The sample was placed inside the chamber without packing or dilution, and the IR spectra were collected by accumulating 64 scans at $4 \mathrm{~cm}^{-1}$ resolution. Prior to methanol adsorption, the catalysts were pretreated at $300{ }^{\circ} \mathrm{C}$ for $1 \mathrm{~h}$ in a flow of $30 \mathrm{NmL} \min ^{-1}$ of $5 \% \mathrm{H}_{2}$ in helium. Methanol adsorption was performed at $100{ }^{\circ} \mathrm{C}$ for 15 min using a stream of He saturated with methanol vapor at room temperature. Then, pure He was passed through the sample and DRIFT spectra were recorded each $50{ }^{\circ} \mathrm{C}$ by increasing the temperature from 100 to $300{ }^{\circ} \mathrm{C}$ different temperatures. All the spectra were subtracted with a background spectrum recorded with an aluminum mirror. The effluent gases were analyzed on-line by mass spectrometry using a Balzers Omnistar system.

\section{Results}

\subsection{General Characterization for Both Catalysts}

Figure 1A,B show the TEM and HRTEM micrographs of the NiSn nanoparticles synthesized, respectively. As can be noticed from Figure 1A, it is evidenced the presence of well-dispersed nanoparticles together with bigger particles of undefined shape constituted by agglomeration of nanoparticles. Figure 1B shows that NiSn nanoparticles are formed by arranging small single crystals in different orientations presenting microdomains of sizes ranging from 2 to $4 \mathrm{~nm}$.

Figure $1 C$ includes the HAADF image and the (energy dispersive $X$-ray) EDX analysis of a representative region of the NiSn nanoparticles having well dispersed as well as agglomerated particles. The chemical composition of the prepared NiSn nanoparticles shows that the material is quite heterogeneous, presenting particles with different compositions. The heterogeneity in the chemical composition could be related to the assembly of small particles with different compositions. It is noteworthy that the $\mathrm{Sn}$ concentration on the agglomerated particles is well above the nominal composition of the samples while the smaller nanoparticles present a lower tin concentration than nominal value. The EDX analysis points to the obtention of nanoparticles in which $\mathrm{Ni}_{3} \mathrm{Sn}, \mathrm{Ni}_{3} \mathrm{Sn}_{2}$ and / or other $\mathrm{Ni}-\mathrm{Sn}$ solid solution are coexisting.

Figure 1D includes the histograms obtained for determining the average particle size of the prepared NiSn nanoparticles. The average size of the nanoparticles is found to be $2.3 \pm 1.1 \mathrm{~nm}$. In our previous work, we stated that the NiSn nanoparticle size is controlled by the amount of PVP added, where the coordination of PVP to the topmost surface atoms determines the growth rate of nanoparticles [21]. Based on this study, the amount of PVP used in the present work was adequate to obtain nanoparticles with an average size of $2 \mathrm{~nm}$.

The prepared NiSn nanoparticles were dispersed onto alumina as detailed in the experimental procedure. In order to expose the nanoparticles completely, the capping agent (PVP) must be fully removed at the appropriated temperature to eliminate all the organic rest but also avoiding the metal nanoparticles sintering. This optimal temperature was determined by thermogravimetric analysis. Figure 2 shows the TG-DTA curve obtained for the as prepared NiSn-Nps catalyst. Firstly, a weak endothermic peak accompanied by a small weight loss are observed above $100{ }^{\circ} \mathrm{C}$ due to the desorption of physisorbed 
water. Around $200{ }^{\circ} \mathrm{C}$, an exothermal peak emerges and simultaneously occurs a fast weight loss revealing that organic matter starts to be burned. The combustion process is completed at around $400{ }^{\circ} \mathrm{C}$. Note that the other two small exothermic peaks accompanied by the slight increase of mass were observed between 400 and $600{ }^{\circ} \mathrm{C}$, which indicates that metal nanoparticles become oxidized in air at this temperature. Based on these results, the NiSn-NPs catalyst was calcined in air at $350{ }^{\circ} \mathrm{C}$.
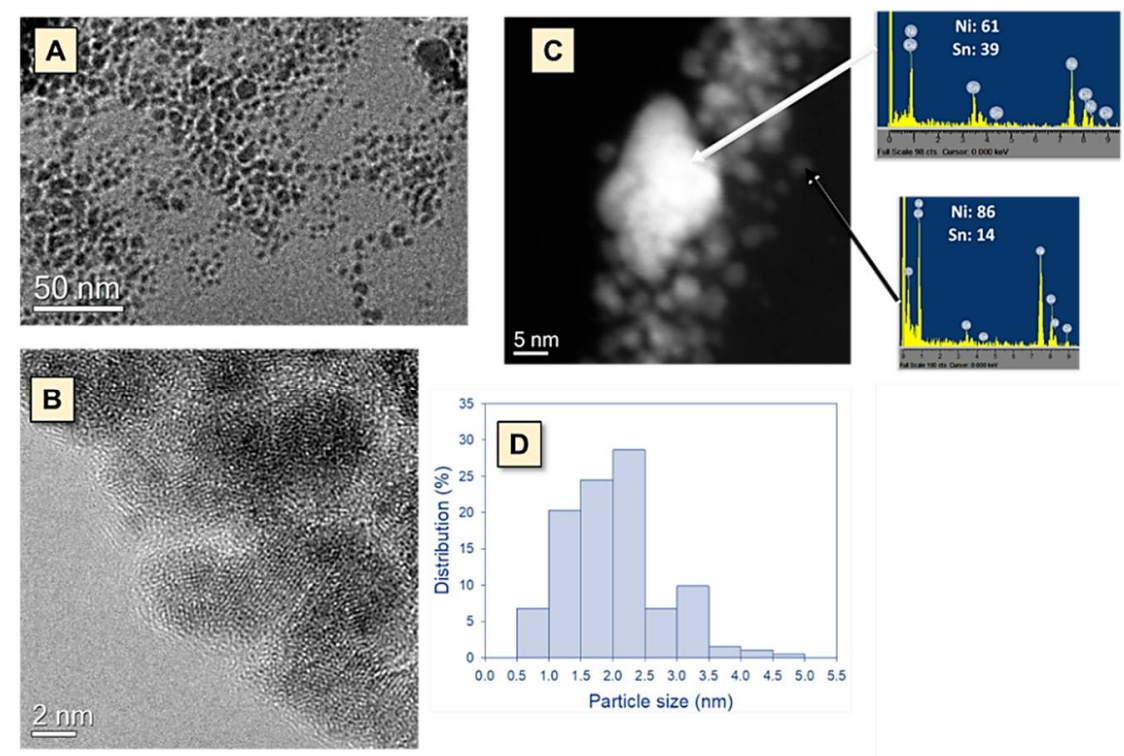

Figure 1. TEM (A) and HRTEM (B) micrographs of synthesized NiSn nanoparticles, EDX analysis of a representative region of the NiSn nanoparticles having well dispersed as well as agglomerated particles (C), and distribution of NiSn particle sizes derived by TEM images (D).

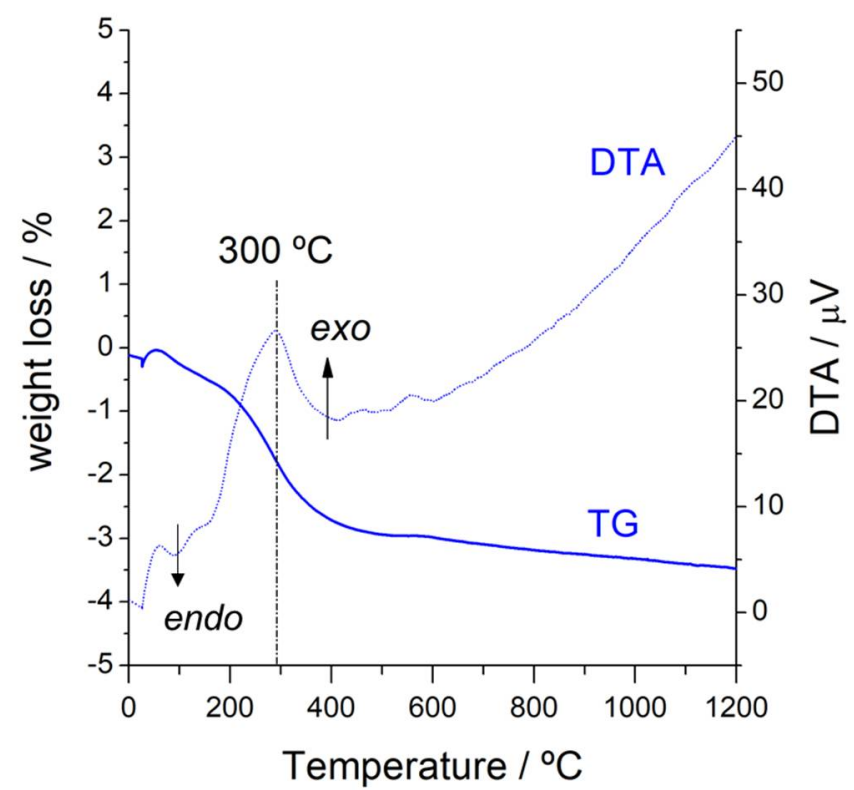

Figure 2. TG-DTA curves of the as prepared NPs-based catalyst (NiSn-NPs).

Figure 3 displays the TPR profiles obtained for both calcined catalysts. As can be observed, the catalyst prepared by impregnation exhibits three main reduction peaks at around $437{ }^{\circ} \mathrm{C}, 570{ }^{\circ} \mathrm{C}$ and $798{ }^{\circ} \mathrm{C}$, which are related to the reduction of nickel phases with a different morphology and/or degree of interaction with the support. According to the literature, the reduction peak at around $437^{\circ} \mathrm{C}$ corresponds to the reduction of large crystallites of nickel oxide weakly interacting with the support while the peak at $570{ }^{\circ} \mathrm{C}$ 
may be ascribed to the reduction of smaller crystallites of nickel oxide [22]. Meanwhile, the reduction peak at higher temperature $\left(798^{\circ} \mathrm{C}\right)$ is mostly related to the reduction of nickel incorporated into the $\mathrm{NiAl}_{2} \mathrm{O}_{4}$ structure, which presents a strong interaction with the support [23]. Concerning the NiSn-Nps catalyst, it can be noted that there only appears one reduction peak at $374{ }^{\circ} \mathrm{C}$. The presence of this low-temperature peak suggests that a thin passive layer of $\mathrm{NiO}$ was formed when the supported NiSn nanoparticles were exposed to atmospheric air in agreement with our previous work [18].

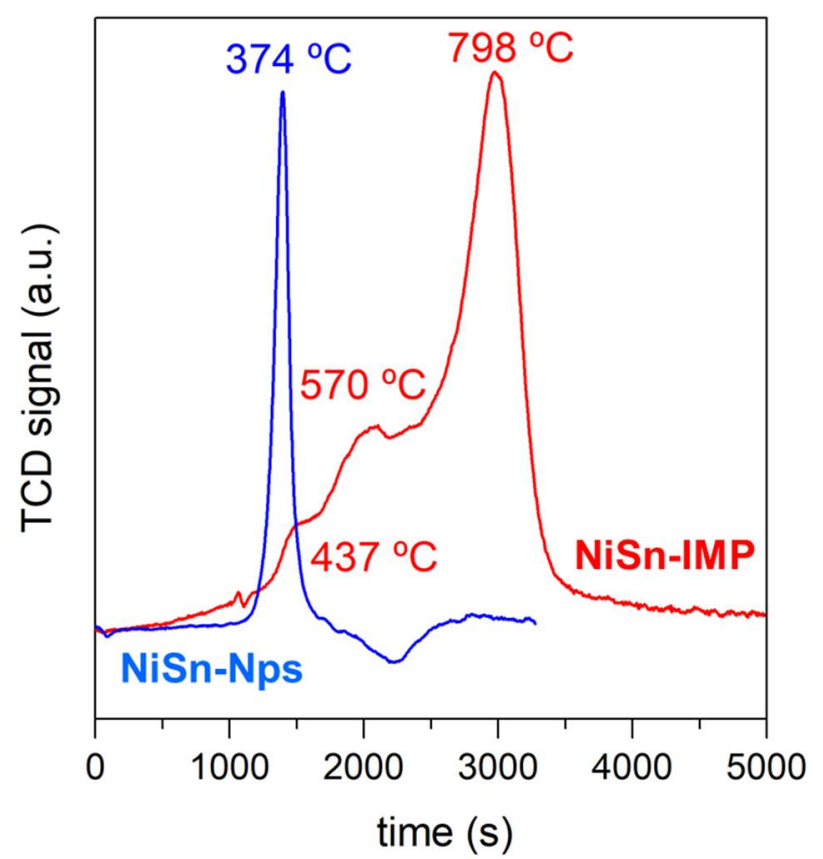

Figure 3. $\mathrm{H}_{2}$-TPR profiles of both calcined catalysts.

The X-ray diffraction patterns of both catalysts calcined and after TPR reduction tests are shown in Figure 4. As can be seen, both fresh catalysts show the diffraction lines at $66.32,45.47$ and $37.36^{\circ}$ associated to the alumina bare support. Note that the NiSn-Nps fresh catalyst shows several reflections related to nanosized NiSn alloys unrevealing that nanoparticles are dispersed onto alumina support. The presence of NiSn intermetallic compounds and the low-temperature calcination $\left(350^{\circ} \mathrm{C}\right)$ inhibits the formation of other phases such as $\mathrm{NiAl}_{2} \mathrm{O}_{4}$. By contrast, diffraction lines corresponding to $\mathrm{NiO}$ species (43.30 and $62.90^{\circ}$ ) were hardly observed in NiSn-IMP fresh catalyst suggesting that surface nickel aluminate is formed as clearly evidenced the slight shift towards smaller $2 \theta$ angles in diffraction lines of alumina. Diffraction lines associated to Sn and/or NiSn phases either were detected in the catalyst prepared by impregnation likely due to the high dispersion or amorphous character of tin in this sample. These observations are in concordance with our previous results already published $[18,24]$.

In order to determine the structural changes produced during the reduction process, X-ray diffraction analyses after TPR tests were also performed. As shown in Figure 4, it is remarkable that the XRD pattern of reduced NiSn-IMP catalyst shows the appearance of three intense diffraction peaks at $44.5,51.9$ and $76.4^{\circ}$ which are ascribed to metallic nickel $\left(\mathrm{Ni}^{0}\right)$ [25]. In addition, it can be observed that there is the presence of low intense reflections that may be related to NiSn intermetallic compounds [18,26]. Furthermore, it is noteworthy that diffraction lines of alumina $\left(66.32,45.47\right.$ and $\left.37.36^{\circ}\right)$ were shifted to higher $2 \theta$ angles after TPR evidencing that $\mathrm{Ni}^{2+}$ ions were rejected from $\mathrm{NiAl}_{2} \mathrm{O}_{4}$ spinel being reduced into metallic nickel and extracting $\mathrm{Al}_{2} \mathrm{O}_{3}$. Therefore, large amounts of metallic nickel and the rest of the NiSn alloys are coexisting in the reduced NiSn-IMP catalyst after reduction at temperatures above $750-800{ }^{\circ} \mathrm{C}$. Concerning the NiSn-Nps reduced catalyst, the appearance of well-defined and intense diffraction peaks after the reducibility test 
clearly evidences that NiSn nanoparticles were agglomerated into large crystals of NiSn alloys compounds with increasing the temperature above $600^{\circ} \mathrm{C}$ during TPR run test. Note that for methanol reforming tests this catalyst was activated at $350{ }^{\circ} \mathrm{C}$ and at this reduction temperature the nanoparticles remain highly dispersed onto alumina support.

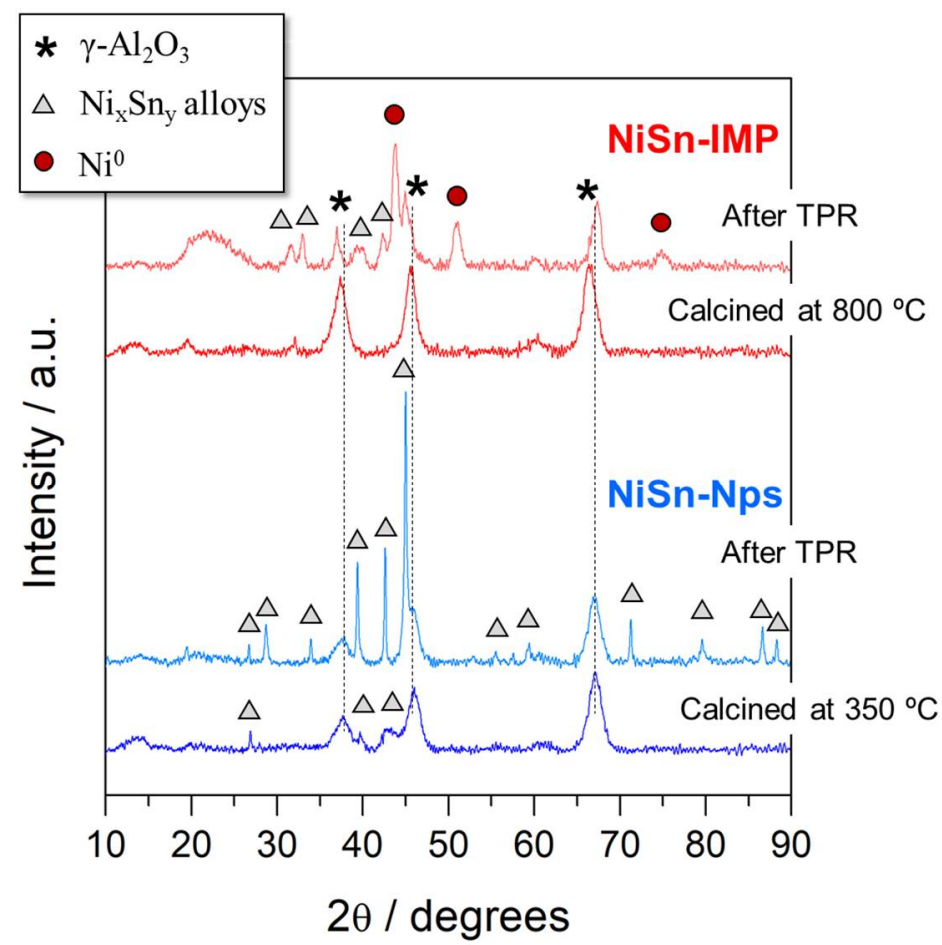

Figure 4. XRD patterns of both NiSn-IMP and NiSn-Nps catalysts calcined and after TPR measurements.

\subsection{Catalytic Performance Testing on Methanol Steam Reforming}

Figure 5 shows the methanol conversion and the $\mathrm{H}_{2} / \mathrm{CO}$ molar ratio as a function of the reaction temperature obtained for both of the two catalysts tested in methanol steam reforming. It can be observed in Figure 5A that methanol conversion increases with the temperature for both catalysts and the catalyst prepared by impregnation (NiSn-IMP) is more active than the catalyst based on supported nanoparticles (NiSn-Nps). These differences in activity can be explained from the structure of the active phase discussed above. The catalyst prepared by impregnation was activated at $800{ }^{\circ} \mathrm{C}$ and the $\mathrm{NiAl}_{2} \mathrm{O}_{4}$ spinel phase was mainly reduced to metallic Ni forming only a small amount of NiSn alloy. Meanwhile, the catalyst based on NiSn nanoparticles was reduced at $350{ }^{\circ} \mathrm{C}$ and the active phase is essentially constituted of nanosized NiSn alloy. As Ni metallic is much more active for cleavage $\mathrm{C}-\mathrm{H}$ bonds than NiSn alloy, it can be deduced that higher methanol conversion will be achieved in NiSn-IMP catalyst. According to the results of our previous studies [18], NiSn nanoparticles based catalysts are less active for methanol steam reforming but notably increase the catalytic stability and inhibit the accumulation of carbonaceous deposits.

On the other hand, Figure $5 \mathrm{~B}$ shows that $\mathrm{H}_{2} / \mathrm{CO}$ molar ratio decreases with increasing the reaction temperature. It is expected that since the reverse water gas-shift reaction will become more favorable than the water gas-shift reaction (Equation (3)) with increasing the reaction temperature. Nevertheless, it is noteworthy that the NiSn-Nps catalyst outperforms NiSn-IMP in terms of $\mathrm{H}_{2} / \mathrm{CO}$ molar ratio. This demonstrates that the presence of NiSn nanoparticles was effective in suppressing CO formation. Hydrogen-rich fuel stream are particularly important for hydrogen supply to PEMFC's fuel cells, which require CO concentrations lower than 100 ppm levels [27]. Typically, Ni-based catalysts are associated to higher $\mathrm{CO}$ production due to its inherent selectivity towards methanol decomposition (Equation (2)) [28]. However, our results demonstrate that NiSn nanoparticles changes the reaction mechanism. This minor $\mathrm{CO}$ production observed for NiSn-Nps catalyst could be 
attributed to the particular electronic properties of the NiSn nanoparticles as active centers for methanol steam reforming. Therefore, this catalytic behavior clearly evidences that small nanosized NiSn particles modifies the catalytic properties of the solid in comparison to the analogous catalytic system prepared by impregnation and demonstrate good potential use for methanol steam reforming reaction.
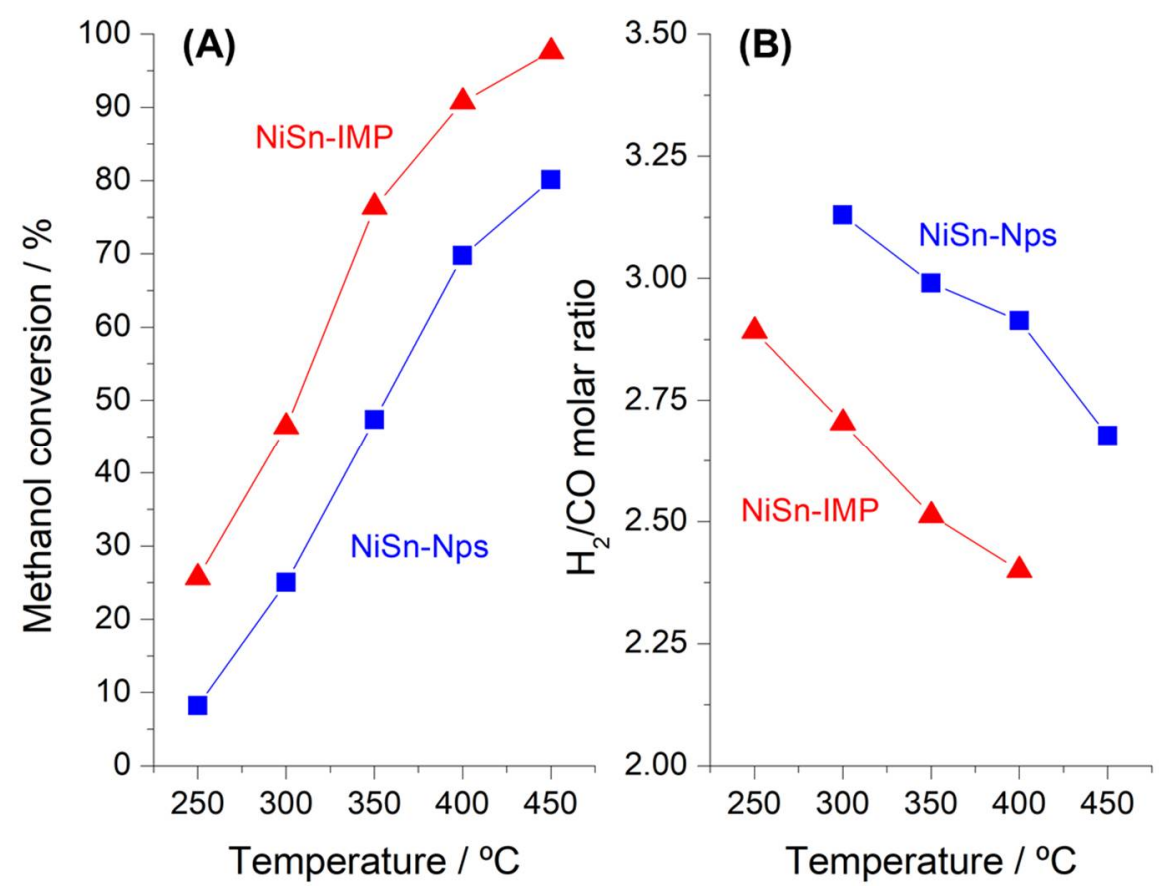

Figure 5. Methanol conversion (A) and $\mathrm{H}_{2} / \mathrm{CO}$ molar ratio $(\mathbf{B})$ as a function of the temperature for the NiSn-IMP and NiSn-Nps catalysts.

\subsection{In Situ DRIFTS-MS Methanol Adsorption Studies}

To further evaluate the differences observed in catalytic activity, we performed an in situ DRIFT spectroscopic study of methanol adsorption to elucidate the intermediates involved in each catalyst during the methanol reforming reaction.

Figure 6 includes the IR spectrum collected after the saturation of methanol at $100{ }^{\circ} \mathrm{C}$ onto the NiSn-IMP catalyst. The emerging bands correspond to the surface species that are formed during methanol adsorption while the vanishing features are related to the hydroxyl surface interacting with methanol during the adsorption process. In fact, the bands at 3736 and $3690 \mathrm{~cm}^{-1}$ can be ascribed to terminal and bridge hydroxyl groups, respectively, according to the model of Knözinger [29]. According to this model, five types different of $\mathrm{OH}$ groups can be distinguished in alumina, and every one of them presents a $v(\mathrm{OH})$ vibrational stretching active mode. In our case, methanol adsorption only affects two types of $\mathrm{OH}$ : (i) terminal hydroxyl, in which oxygen is bonded to one metallic atom of the surface, and (ii) bridge hydroxyl with an oxygen bridged to two metallic atoms. Moreover, it can be noticed in Figure 6 the appearance of a broad band centred at around $3300 \mathrm{~cm}^{-1}$, which is assigned to hydroxyl groups interacting by hydrogen bonds with physisorbed methanol [30].

Regarding the adsorbed species formed after methanol adsorption, it is clearly evident that there is the appearance of two intense bands at 1059 and $1000 \mathrm{~cm}^{-1}$ ascribed to the $v(\mathrm{CO})$ stretching modes of methoxide groups [31]. The appearance of more than one band in this region is related to the presence of methoxide species with different coordination. According to Lamotte et al. [32], it can be stated that the band at $1059 \mathrm{~cm}^{-1}$ corresponds to the $v(\mathrm{CO})$ vibrational mode of monodentate methoxides while the band at $1000 \mathrm{~cm}^{-1} \mathrm{can}$ be ascribed methoxide with coordination bridge-type. This attribution is based on the type of $\mathrm{OH}$ groups affected by the adsorption of the alcohol (monodentates and bridge). On 
the other side, the positive band of very low intensity observed at $3658 \mathrm{~cm}^{-1}$ corresponds to adsorbed methanol species without dissociating and this band is associated to another broad band which emerged at $1440 \mathrm{~cm}^{-1}$. Furthermore, in the $3100-2700 \mathrm{~cm}^{-1}$ region appears a complex set of overlapped bands ascribed to the $v(\mathrm{C}-\mathrm{H})$ vibration modes of methyl groups coming from dissociated and no-dissociated methanol adsorbed species [30]. Finally, the band that appears at $2070 \mathrm{~cm}^{-1}$ can be assigned to the presence of CO linearly adsorbed on Ni sites [33]. Although this band is low intense, it reveals that this catalyst is able to produce $\mathrm{CO}$ at $100{ }^{\circ} \mathrm{C}$, which is a by-product of steam reforming of methanol. The simultaneous production of $\mathrm{CO}$ and $\mathrm{H}_{2}$ resulting of methanol decomposition during the adsorption step is already proposed by some authors [31].

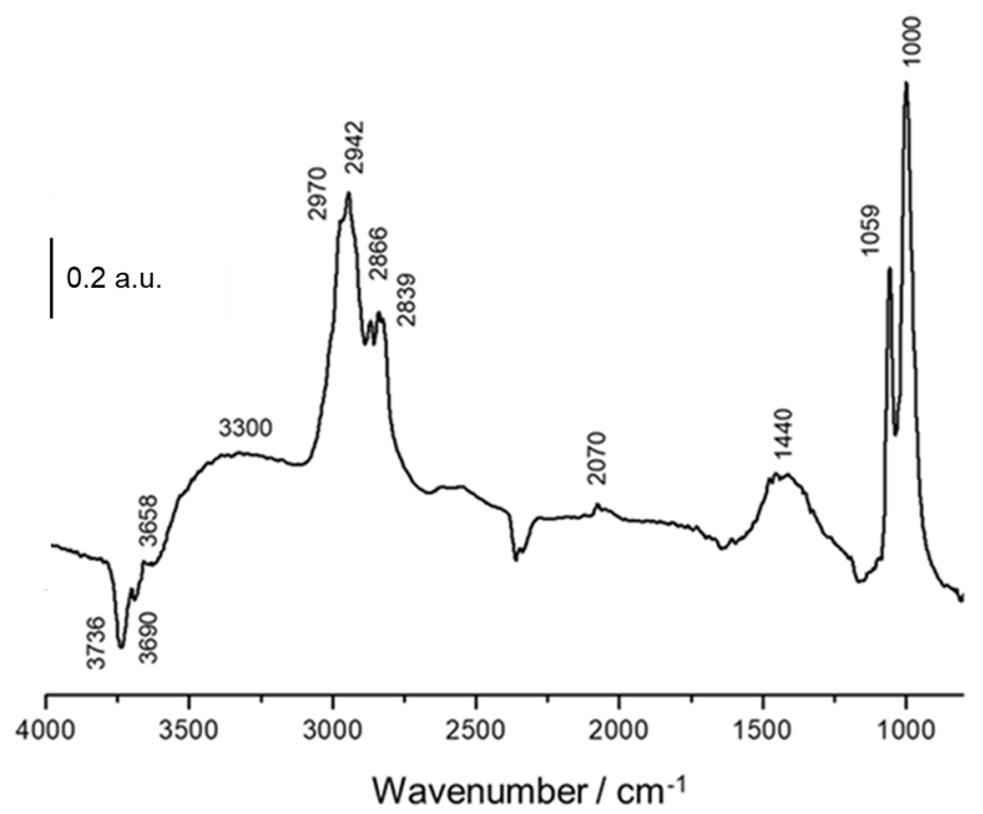

Figure 6. DRIFT spectra of NiSn-IMP catalyst after adsorption of methanol at $100{ }^{\circ} \mathrm{C}$.

Figure 7 shows the DRIFT spectrum recorded after the saturation of methanol at $100{ }^{\circ} \mathrm{C}$ onto NiSn-Nps catalyst. In this case, the observed bands identical than that of NiSnIMP sample, and thus all of them can be attributed to the same species, but an important difference was observed. In contrast to NiSn-IMP, the intensity of the band related to monodentate methoxide species $\left(1057 \mathrm{~cm}^{-1}\right)$ is more major than that of one associated to bridge methoxide species $\left(1009 \mathrm{~cm}^{-1}\right)$. This indicates that the preparation method based on deposition of NiSn nanoparticles leads to minor concentration of surface bridge hydroxyls over the surface and consequently it does affect directly to the methoxide intermediate species formed during methanol adsorption.

After saturation of catalyst surface with methanol at $100{ }^{\circ} \mathrm{C}$, the sample was purged with helium flow, maintaining the temperature during $5 \mathrm{~min}$, and subsequently the temperature was progressively increased up to $300^{\circ} \mathrm{C}$. In order to clearly appreciate the thermal evolution of the surface species, the spectrum recorded at each temperature was subtracted from a reference spectrum collected after methanol saturation. Thus, the negative bands correspond to species that are disappearing during the thermal treatment whereas the positive ones represent the formed species at each temperature. Moreover, the effluent stream was monitored by MS to correlate the adsorbed surface species with the desorbed products. It must be pointed out that the measured MS signals only give a qualitative idea of the evolution of different products. 


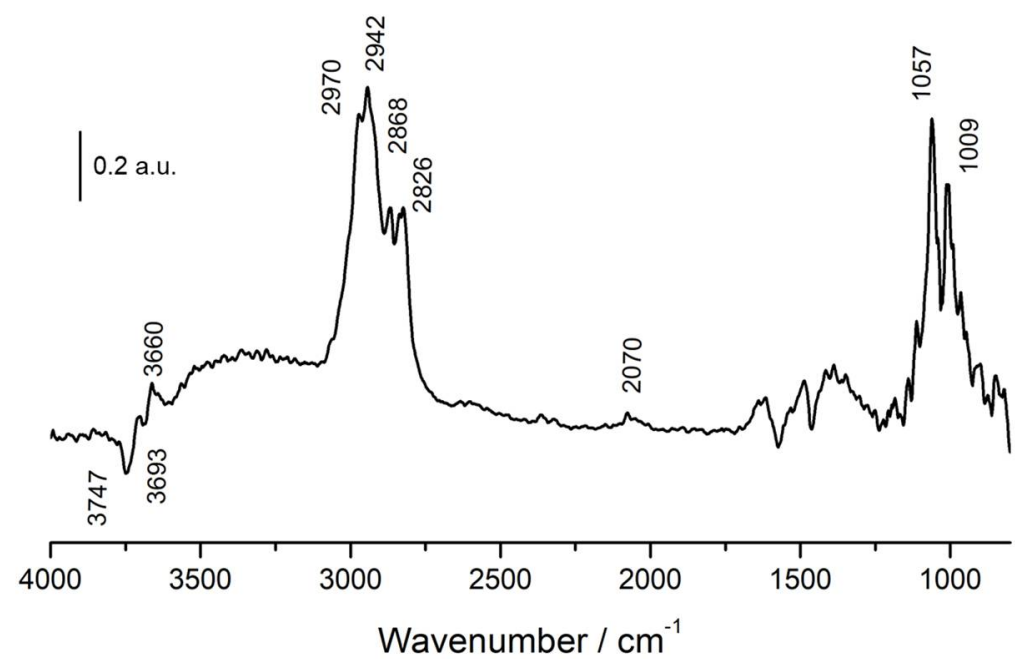

Figure 7. DRIFT spectra of NiSn-Nps catalyst after adsorption of methanol at $100{ }^{\circ} \mathrm{C}$.

Figure 8 illustrates the thermal evolution of the adsorbed species on NiSn-IMP catalyst. As can be observed, at $200{ }^{\circ} \mathrm{C}$ there takes place the disappearance of both bands at 1059 and $1000 \mathrm{~cm}^{-1}$ related to the $v(\mathrm{CO})$ vibration modes of the methoxide species adsorbed with different coordination geometry. Additionally, it is also noticed that features at $2800-3000 \mathrm{~cm}^{-1}$ related to $v(\mathrm{CH})$ vibration modes and the band at $2070 \mathrm{~cm}^{-1}$ typical of CO-linearly adsorbed on nickel also disappeared at $200^{\circ} \mathrm{C}$. Moreover, it is noteworthy that bands attributed to species linked by hydrogen bonds ( 3300 and $1450 \mathrm{~cm}^{-1}$ ) vanished and the features of surface hydroxyl groups emerged simultaneously. On the other hand, it can be noticed that as temperature increased a new band appeared at $1590 \mathrm{~cm}^{-1}$. This band is related to formate intermediates, and their formation indicates that methoxide species are transformed into formates. It is worth mentioning that formate species are characterized by three bands at 1590,1390 and $1370 \mathrm{~cm}^{-1}$, which correspond to the $v_{\text {as }}(\mathrm{COO})$ asymmetric COO stretching mode, the $\delta(\mathrm{CH})$ out-of-plane bending $\mathrm{CH}$ mode and the $v_{\mathrm{s}}(\mathrm{COO})$ symmetric COO stretching mode, respectively [34].The bands at 1390 and $1370 \mathrm{~cm}^{-1}$ are only detected at $300{ }^{\circ} \mathrm{C}$ because they are masked by the broad negative band around $1440 \mathrm{~cm}^{-1}$ at lower temperatures.

Figure 9 shows the evolution of the effluent stream followed by MS during the thermal treatment. At $100{ }^{\circ} \mathrm{C}$, it can be observed the release of water, $\mathrm{CO}$, methanol and hydrogen, which is in concordance with the adsorbed species detected in the DRIFT spectrum (Figure 7). This reveals that this catalyst can produce $\mathrm{H}_{2}$ and $\mathrm{CO}$ from methanol at $100{ }^{\circ} \mathrm{C}$. On the other side, it is worth mentioning that the transformation of methoxide species in formates can produce hydrogen with the simultaneous surface reduction of the support since at $200{ }^{\circ} \mathrm{C}$ no modification was observed in the intensity of the formates DRIFT bands (Figure 7) and the $\mathrm{m} / \mathrm{z}$ signal of hydrogen falls to zero in the MS (Figure 8). In a first approach, we can suggest that part of the produced hydrogen can be due to the transformation of methoxides into formates via reduction of support, although the confirmation of this fact requires further studies. As temperature was increased at $200{ }^{\circ} \mathrm{C}$, dimethyl ether (DME) was detected in the stream effluent. Carrizosa et al. [35] proposed a mechanism for explaining the formation of dimethyl ether by a reaction between adsorbed methoxy species during methanol adsorption on anatasa. Accordingly, the surface reaction occurs when a certain coverage of the so-called labile alcoholates is achieved and it requires the presence of acid sites. We believe that these conditions are satisfied in the NiSn-IMP catalyst when desorption temperature was increased. 


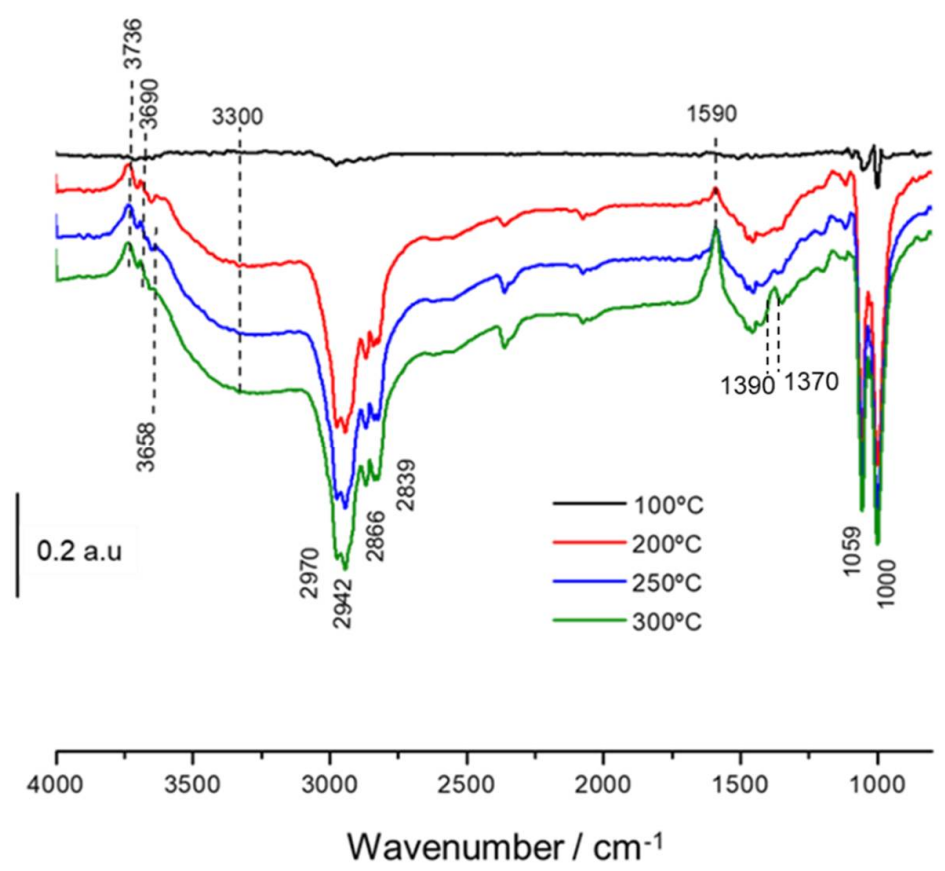

Figure 8. Thermal evolution of difference spectra after methanol adsorption at $100{ }^{\circ} \mathrm{C}$ under flow of helium at $100{ }^{\circ} \mathrm{C}, 200{ }^{\circ} \mathrm{C}, 250{ }^{\circ} \mathrm{C}$ and $300^{\circ} \mathrm{C}$ on NiSn-IMP catalyst.
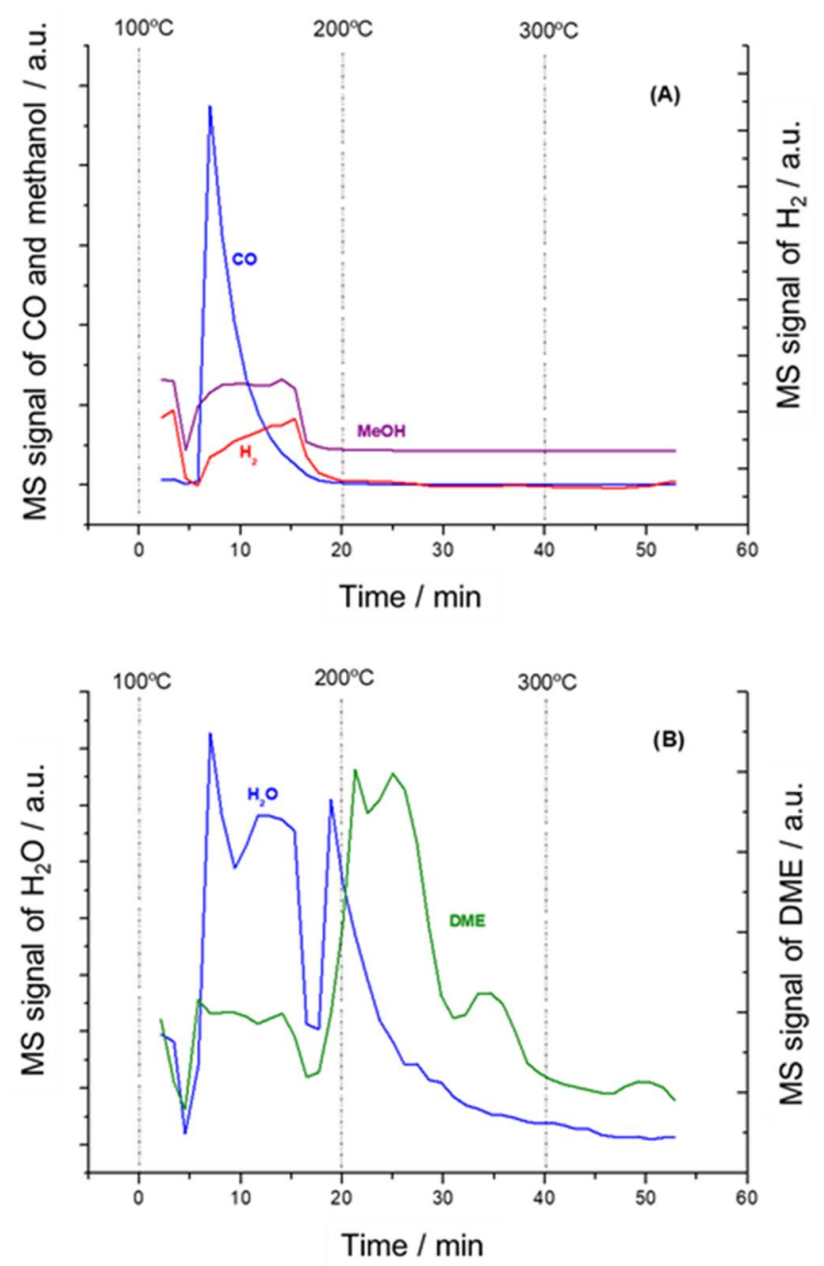

Figure 9. Evolution of MS signal intensities recorded as a function of time and temperature during the desorption of adsorbed methanol over NiSn-IMP sample: (A) CO, $\mathrm{H}_{2}$ and methanol; (B) $\mathrm{H}_{2} \mathrm{O}$ and DME. 
Figure 10 displays the thermal evolution of the adsorbed species on the NiSn-Nps catalyst. It must be emphasized that notable differences are observed in comparison with the impregnated catalyst. Indeed, as the temperature is increased, the diminution of the band at $1057 \mathrm{~cm}^{-1}$ related to monodentate methoxides is much faster than that of band at $1009 \mathrm{~cm}^{-1}$ ascribed to bridge-coordinated methoxides. This observation is in concordance with the lower thermal stability of monodentate methoxides. Further, it should be noted that a slight increase of the bands at 1030 and $1009 \mathrm{~cm}^{-1}$ occurs under helium flow at $100-200{ }^{\circ} \mathrm{C}$, which can be attributed to the presence of non-dissociated methanol adsorbed $\left(1030 \mathrm{~cm}^{-1}\right)$ and bridge-coordinated methoxides $\left(1009 \mathrm{~cm}^{-1}\right)$. Remarkably, the appearance of these two bands is accompanied by a slight decrease of the band around $3700 \mathrm{~cm}^{-1}$. The increase of the band at $1009 \mathrm{~cm}^{-1}$ and the simultaneous diminution of the band at $3700 \mathrm{~cm}^{-1}$ reveal the presence of bridge-coordinated methoxides formed from the adsorbed methanol. As mentioned above, bridge methoxides are thermally more stables than monodentate ones. As the temperature was increased above $200{ }^{\circ} \mathrm{C}$, the most stables bridge methoxides disappeared and three new bands at 1596, 1390 and $1370 \mathrm{~cm}^{-1}$ ascribed to formate species emerged simultaneously [34]. In comparison with NiSn-IMP catalysts, the formation of formate species occurs more slowly in this case and besides the intensity of the bands increased with the temperature.

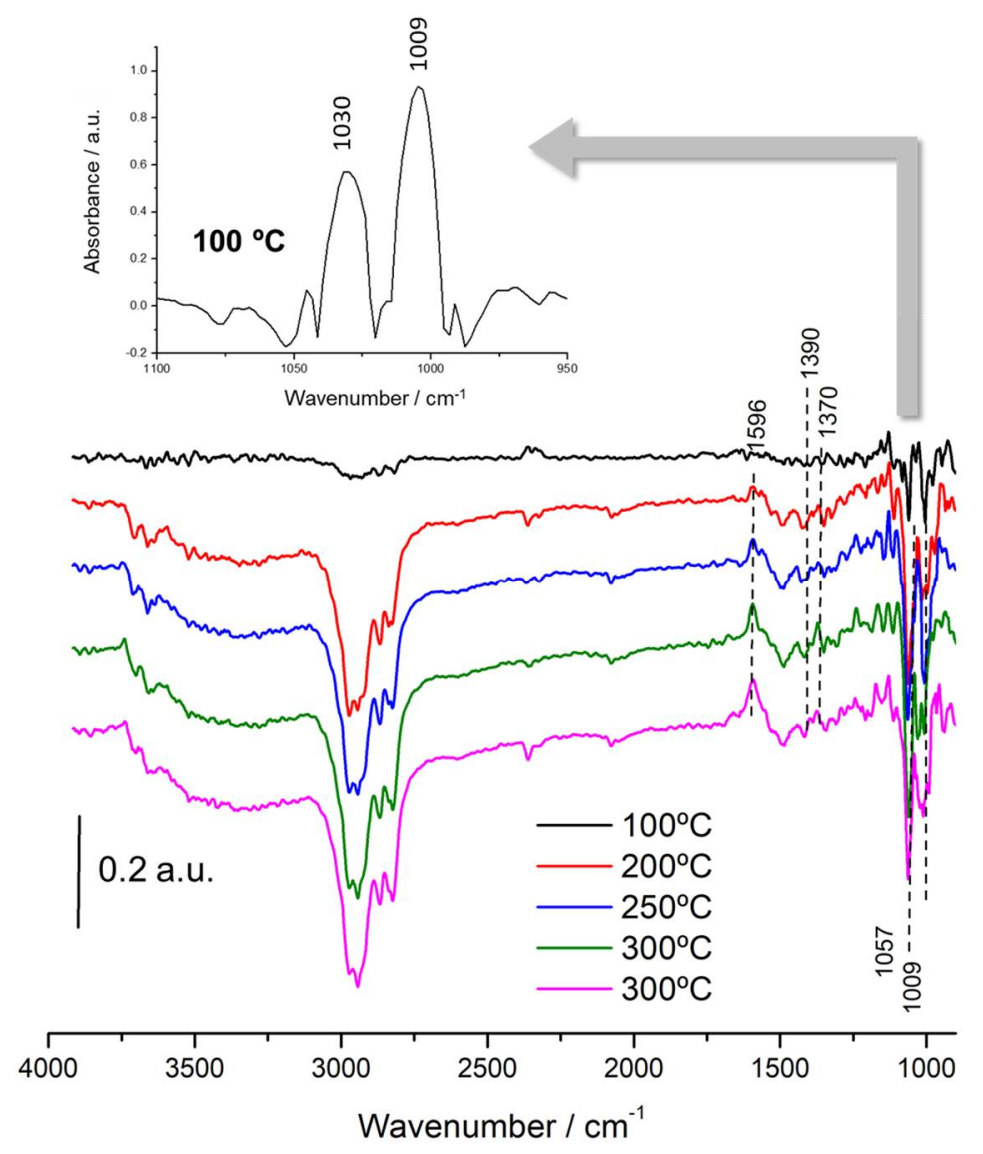

Figure 10. Thermal evolution of difference spectra after methanol adsorption at $100{ }^{\circ} \mathrm{C}$ under flow of helium at $100{ }^{\circ} \mathrm{C}, 200{ }^{\circ} \mathrm{C}, 250{ }^{\circ} \mathrm{C}$ and $300^{\circ} \mathrm{C}$ on NiSn-Nps catalyst.

Figure 11 shows the evolution of mass spectrometer signal intensities recorded as a function of time and temperature during the desorption of adsorbed methanol on NiSn-Nps catalyst. It should be noted that methanol was desorbed even at temperatures above $200^{\circ} \mathrm{C}$. In concordance with the DRIFT spectra shown in Figure 10, it can be assumed that methoxide species weakly adsorbed (monodentate geometry) are transformed into methanol at $150-200{ }^{\circ} \mathrm{C}$. This suggestion is in agreement with the data reported by Lamotte et al. [32]. 
Moreover, it explains the presence of non-dissociated methanol still adsorbed at $200{ }^{\circ} \mathrm{C}$. Meanwhile, the desorbed methanol detected in NiSn-IMP sample at $100-150{ }^{\circ} \mathrm{C}$ is essentially attributed to rests of physisorbed methanol (see Figure 9).

On the other side, it can be observed that NiSn-Nps catalyst also produces $\mathrm{CO}$ and $\mathrm{H}_{2}$ by methanol decomposition between 100 and $200{ }^{\circ} \mathrm{C}$. This indicates that the NiSn-Nps catalyst also presents an optimal activity for steam reforming of methanol. However, differently to NiSn-IMP, it must be remarked that hydrogen was also produced at temperatures above $300{ }^{\circ} \mathrm{C}$. This suggests that NiSn nanoparticles facilitates the decomposition of formates into hydrogen and $\mathrm{CO}_{2}$ and explain the higher hydrogen production observed in NiSn-Nps catalyst in catalytic tests of methanol steam reforming. Finally, Figure 10 indicates that DME was also produced in NiSn-Nps catalyst above $200^{\circ} \mathrm{C}$ but their formation was more prolongated with time-on-stream. This fact suggests that NiSn-Nps catalyst contains superficial species, likely a higher concentration of strong acid sites, that leads to the formation of DME methanol dehydration. Notwithstanding, this assertion requires further studies of acid-base properties and herein it is only indirectly assumed.
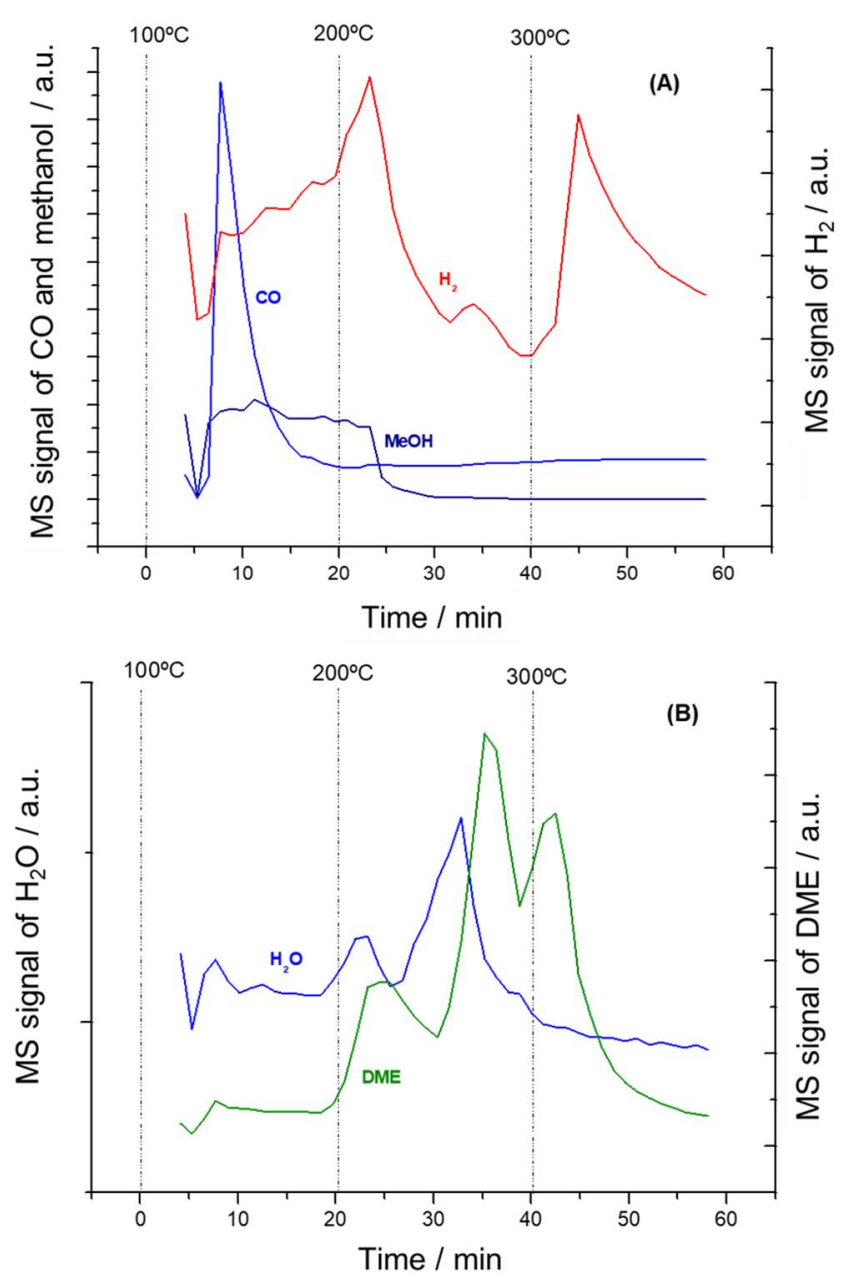

Figure 11. Evolution of MS signal intensities recorded as a function of time and temperature during the desorption of adsorbed methanol over NiSn-Nps sample. (A) CO, $\mathrm{H}_{2}$ and methanol; (B) $\mathrm{H}_{2} \mathrm{O}$ and DME.

\subsection{Mechanistic Insights}

From a mechanistic point of view, the experimental results of this work show that the production of hydrogen by methanol steam reforming is sensitively affected by size of active metal. From an in situ DRIFTS-MS study, it can de deduced that the adsorption of methanol on the catalyst is mainly dissociative and methoxy intermediates with different 
geometry are formed on the active sites and over inert regions of the catalyst surface mainly associated to alumina. Our results suggest that part of these methoxy groups, likely those located at the metal-support interface or on metal sites, transform easily to formate species, which subsequently are decomposed into hydrogen and $\mathrm{CO}_{2}$. Some authors have proposed that the transformation of methoxy groups into formate species occurs via intermediacy of dioxymethylene species [36]. However, these intermediates are highly unstable and cannot be detected by DRIFTS during the reaction process. Figure 12 illustrates a tentative reaction pathway for the methanol steam reforming process. As mentioned in the introduction section, the steam reforming reaction is formally the sum of methanol decomposition and water gas shift reaction. Accordingly, $\mathrm{CO}$ produced by methanol decomposition can be transformed into $\mathrm{CO}_{2}$ and $\mathrm{H}_{2}$ via WGS reaction likely also through the formation of formate intermediates at the interface sites. The presence of steam during methanol decomposition displaces the production of $\mathrm{CO}$ towards hydrogen and $\mathrm{CO}_{2}$. The reaction scheme also includes methoxy condensation to DME that probably involves the acid sites of alumina, being a well-known acid-catalyzed reaction $[36,37]$. On the basis of the obtained results, it seems reasonable to assume that the reaction mechanisms for methanol steam reforming in both catalysts are closely related, and that the surface phenomena occurring are very similar. However, NiSn nanoparticles dispersed onto alumina increases the number of metal-support interface sites exposed and favor the formate decomposition increasing the hydrogen yield.

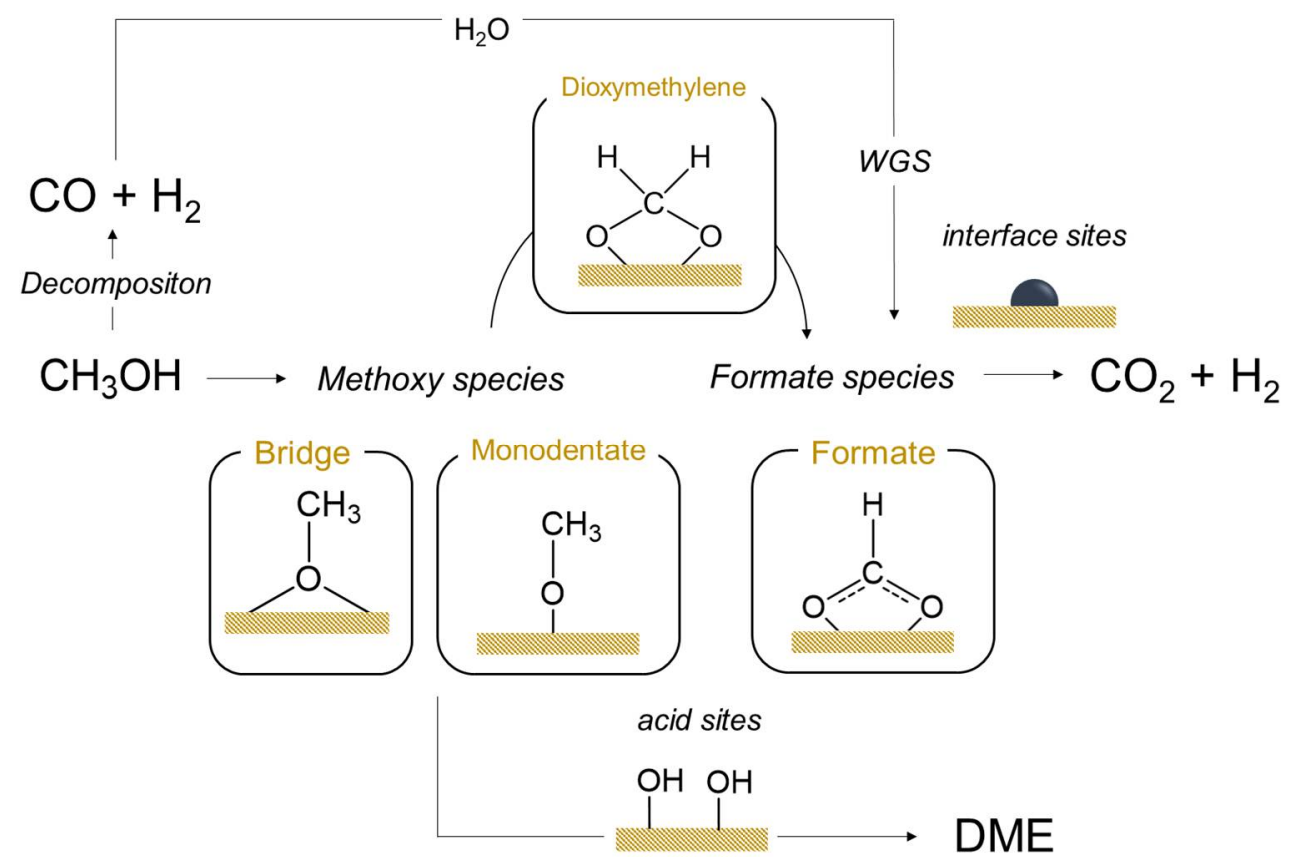

Figure 12. Tentative reaction mechanism proposed for methanol steam reforming reaction.

\section{Conclusions}

This study provides new insights into the reaction mechanism of methanol steam reforming for hydrogen production both supported NiSn nanoparticles and analogous NiSn catalyst prepared by impregnation. In situ DRIFTS-MS measurements revealed that different intermediate species such as methoxides with different geometry (bridge and monodentate) and formate species are the most involved in the methanol steam reforming reaction in both catalysts. Our results point out that methoxy groups mainly located at the metal-support interface are more easily transformed into formate species, which subsequently are decomposed into hydrogen and $\mathrm{CO}_{2}$. Consequently, the major presence of metal-support interface sites in supported NiSn Nps leads to a higher hydrogen yield. 
Author Contributions: Conceptualization, F.R.-S.; methodology, L.F.B. and F.R.-S.; validation, A.-C.R., F.R.-S. and J.A.O.; formal analysis, F.R.-S.; investigation, L.F.B., L.A., S.I., M.A.C., J.J.D. and F.R.-S.; resources, A.-C.R.; data curation, F.R.-S.; writing-original draft preparation, L.F.B.; writing-review and editing, F.R.-S. and J.A.O.; visualization, L.F.B.; supervision, J.A.O.; project administration, J.A.O.; funding acquisition, J.A.O. All authors have read and agreed to the published version of the manuscript.

Funding: Financial support for this work was obtained from Junta de Andalucía (POG-TEP01965) co-funded by FEDER fund from the European Union.

Conflicts of Interest: The authors declare no conflict of interest.

\section{References}

1. Liobikiene, G.; Butkus, M. The European Union possibilities to achieve targets of Europe 2020 and Paris agreement climate policy. Renew. Energy 2017, 106, 298-309. [CrossRef]

2. Gholami, P.; Khataee, A.; Bhatnagar, A.; Vahid, B. Synthesis of N-doped magnetic $\mathrm{WO}_{3}-\mathrm{x} @$ Mesoporous carbon using a diatom template and plasma modification: Visible-light-driven photocatalytic activities. ACS Appl. Mater. Interfaces 2021, 13, 13072-13086. [CrossRef] [PubMed]

3. Gholami, P.; Khataee, A.; Bhatnagar, A. Photocatalytic degradation of antibiotic and hydrogen production using diatom-templated 3D $\mathrm{WO}_{3}-\mathrm{x} @$ mesoporous carbon nanohybrid under visible light irradiation. J. Clean. Prod. 2020, 275, 124157. [CrossRef]

4. Garcia, G.; Arriola, E.; Chen, W.-H.; De Luna, M.D. A comprehensive review of hydrogen production from methanol thermochemical conversion for sustainability. Energy 2020, 217, 119384. [CrossRef]

5. Abbandanak, M.H.; Taghizadeh, M.; Fallah, N. High-purity hydrogen production by sorption-enhanced methanol steam reforming over a combination of $\mathrm{Cu}-\mathrm{Zn}-\mathrm{CeO}_{2}-\mathrm{ZrO}_{2} / \mathrm{MCM}-41$ catalyst and ( $\left.\mathrm{Li}-\mathrm{Na}-\mathrm{K}\right) \mathrm{NO}_{3} \cdot \mathrm{MgO}$ adsorbent. Int. J. Hydrog. Energy 2021, 46, 7099-7112. [CrossRef]

6. Sá, S.; Silva, H.; Brandão, L.; Sousa, J.; Mendes, A. Catalysts for methanol steam reforming-A review. Appl. Catal. B Environ. 2010, 99, 43-57. [CrossRef]

7. Yao, C.-Z.; Wang, L.-C.; Liu, Y.-M.; Wu, G.-S.; Cao, Y.; Dai, W.-L.; He, H.-Y.; Fan, K.-N. Effect of preparation method on the hydrogen production from methanol steam reforming over binary $\mathrm{Cu} / \mathrm{ZrO}_{2}$ catalysts. Appl. Catal. A Gen. 2006, 297, 151-158. [CrossRef]

8. Shishido, T.; Yamamoto, Y.; Morioka, H.; Takaki, K.; Takehira, K. Active $\mathrm{Cu} / \mathrm{ZnO}$ and $\mathrm{Cu} / \mathrm{ZnO} / \mathrm{Al}_{2} \mathrm{O}_{3}$ catalysts prepared by homogeneous precipitation method in steam reforming of methanol. Appl. Catal. A Gen. 2004, 263, 249-253. [CrossRef]

9. Águila, G.; Jiménez, J.; Guerrero, S.; Gracia, F.; Chornik, B.; Quinteros, S.; Araya, P. A novel method for preparing high surface area copper zirconia catalysts: Influence of the preparation variables. Appl. Catal. A Gen. 2009, 360, 98-105. [CrossRef]

10. Iulianelli, A.; Ribeirinha, P.; Mendes, A.; Basile, A. Methanol steam reforming for hydrogen generation via conventional and membrane reactors: A review. Renew. Sustain. Energy Rev. 2014, 29, 355-368. [CrossRef]

11. Jeong, H.; Kim, K.I.; Kim, T.H.; Ko, C.H.; Park, H.C.; Song, I.K. Hydrogen production by steam reforming of methanol in a micro-channel reactor coated with $\mathrm{Cu} / \mathrm{ZnO} / \mathrm{ZrO}_{2} / \mathrm{Al}_{2} \mathrm{O}_{3}$ catalyst. J. Power Sources 2006, 159, 1296-1299. [CrossRef]

12. Papavasiliou, J.; Avgouropoulos, G.; Ioannides, T. Steam reforming of methanol over copper-manganese spinel oxide catalysts. Catal. Commun. 2005, 6, 497-501. [CrossRef]

13. Dasireddy, V.D.; Likozar, B. Cu-Mn-O nano-particle/nano-sheet spinel-type materials as catalysts in methanol steam reforming (MSR) and preferential oxidation (PROX) reaction for purified hydrogen production. Renew. Energy 2021, 182, 713-724. [CrossRef]

14. Bossola, F.; Roongcharoen, T.; Coduri, M.; Evangelisti, C.; Somodi, F.; Sementa, L.; Fortunelli, A.; Santo, V.D. Discovering indium as hydrogen production booster for a $\mathrm{Cu} / \mathrm{SiO}_{2}$ catalyst in steam reforming of methanol. Appl. Catal. B Environ. 2021, $297,120398$. [CrossRef]

15. Pérez-Hernández, R. Reactivity of $\mathrm{Pt} / \mathrm{Ni}$ supported on $\mathrm{CeO}_{2}$-nanorods on methanol steam reforming for $\mathrm{H}_{2}$ production: Steady state and DRIFTS studies. Int. J. Hydrog. Energy 2021, 46, 25954-25964. [CrossRef]

16. Conant, T.; Karim, A.M.; Lebarbier, V.; Wang, Y.; Girgsdies, F.; Schlögl, R.; Datye, A. Stability of bimetallic Pd-Zn catalysts for the steam reforming of methanol. J. Catal. 2008, 257, 64-70. [CrossRef]

17. Iwasa, N.; Mayanagi, T.; Nomura, W.; Arai, M.; Takezawa, N. Effect of Zn addition to supported Pd catalysts in the steam reforming of methanol. Appl. Catal. A Gen. 2003, 248, 153-160. [CrossRef]

18. Bobadilla, L.; Palma, S.; Ivanova, S.; Domínguez, M.; Romero-Sarria, F.; Centeno, M.; Odriozola, J. Steam reforming of methanol over supported $\mathrm{Ni}$ and Ni-Sn nanoparticles. Int. J. Hydrog. Energy 2013, 38, 6646-6656. [CrossRef]

19. Zhou, Y.; Jin, C.; Li, Y.; Shen, W. Dynamic behavior of metal nanoparticles for catalysis. Nano Today 2018, 20, 101-120. [CrossRef]

20. Huttunen, P.K.; Labadini, D.; Hafiz, S.S.; Gokalp, S.; Wolff, E.P.; Martell, S.M.; Foster, M. DRIFTS investigation of methanol oxidation on $\mathrm{CeO}_{2}$ nanoparticles. Appl. Surf. Sci. 2021, 554, 149518. [CrossRef]

21. Bobadilla, L.F.; Garcia, C.; Delgado, J.J.; Sanz, O.; Romero-Sarria, F.; Centeno, M.A.; Odriozola, J.A. Influence of PVP in magnetic properties of NiSn nanoparticles prepared by polyol method. J. Magn. Magn. Mater. 2012, 324, 4011-4018. [CrossRef]

22. Richardson, J.T.; Twigg, M.V. Reduction of impregnated $\mathrm{NiO} / \alpha-\mathrm{Al}_{2} \mathrm{O}_{3}$ association of $\mathrm{Al}^{3+}$ ions with NiO. Appl. Catal. A Gen. 1998, 167, 57-64. [CrossRef] 
23. Jacob, K.T.; Alcock, C.B. Activities and their relation to cation distribution in $\mathrm{NiAl}_{2} \mathrm{O}_{4} / \mathrm{MgAl}_{2} \mathrm{O}_{4}$ spinel solid solutions. J. Solid State Chem. 1977, 20, 79-88. [CrossRef]

24. Penkova, A.D.; Bobadilla, L.; Ivanova, S.; Domínguez, M.; Romero-Sarria, F.; Roger, A.-C.; Centeno, M.; Odriozola, J.A. Hydrogen production by methanol steam reforming on $\mathrm{NiSn} / \mathrm{MgO}-\mathrm{Al}_{2} \mathrm{O}_{3}$ catalysts: The role of $\mathrm{MgO}$ addition. Appl. Catal. A Gen. 2011, 392, 184-191. [CrossRef]

25. Richardson, J.T.; Scates, R.; Twigg, M.V. X-ray diffraction study of nickel oxide reduction by hydrogen. Appl. Catal. A Gen. 2003, 246, 137-150. [CrossRef]

26. Gao, S.; Huang, H.; Wu, A.; Yu, J.; Gao, J.; Dong, X.; Liu, C.; Cao, G. Formation of Sn-M (M = Fe, Al, Ni) alloy nanoparticles by DC arc-discharge and their electrochemical properties as anodes for Li-ion batteries. J. Solid State Chem. 2016, 242, 127-135. [CrossRef]

27. Adcock, P.A.; Pacheco, S.V.; Norman, K.M.; Uribe, F.A. Transition metal oxides as reconfigured fuel cell anode catalysts for improved CO tolerance: Polarization data. J. Electrochem. Soc. 2005, 152, A459. [CrossRef]

28. Khzouz, M.; Gkanas, E.I.; Du, S.; Wood, J. Catalytic performance of $\mathrm{Ni}-\mathrm{Cu} / \mathrm{Al}_{2} \mathrm{O}_{3}$ for effective syngas production by methanol steam reforming. Fuel 2018, 232, 672-683. [CrossRef]

29. Knözinger, H. Dehydration of alcohols on aluminum oxide. Angew. Chem. Int. Ed. 1968, 7, 791-805. [CrossRef]

30. Vigué, H.; Quintard, P.; Merle-Méjeana, T.; Lorenzelli, V. FT-IR study of $\mathrm{CH}_{3} \mathrm{OH}$ adsorption on chlorinated $\gamma$-aluminas. J. Eur. Ceram. Soc. 1998, 18, 1753-1757. [CrossRef]

31. Busca, G. Infrared studies of the reactive adsorption of organic molecules over metal oxides and of the mechanisms of their heterogeneously-catalyzed oxidation. Catal. Today 1996, 27, 457-496. [CrossRef]

32. LaMotte, J.; Moravek, V.; Bensitel, M.; LaValley, J.C. FT-IR study of the structure and reactivity of methoxy species on $\mathrm{ThO}_{2}$ and $\mathrm{CeO}_{2}$. React. Kinet. Catal. Lett. 1988, 36, 113-118. [CrossRef]

33. Hadjivanov, K.I.; Vayssilov, G.N. Characterization of oxide surfaces and zeolites by carbon monoxide as an IR probe molecule. ChemInform 2003, 34, 17296. [CrossRef]

34. Greenler, R.G. Infrared study of the adsorption of methanol and ethanol on aluminum oxide. J. Chem. Phys. 1962, 37, 2094-2100. [CrossRef]

35. Carrizosa, I.; Munuera, G.; Castañar, S. Study of the interaction of aliphatic alcohols with $\mathrm{TiO}_{2}$ : III. Formation of alkyl-titanium species during methanol decomposition. J. Catal. 1977, 49, 265-277. [CrossRef]

36. Turco, M.; Bagnasco, G.; Costantino, U.; Marmottini, F.; Montanari, T.; Ramis, G.; Busca, G. Production of hydrogen from oxidative steam reforming of methanolII. Catalytic activity and reaction mechanism on $\mathrm{Cu} / \mathrm{ZnO} / \mathrm{Al}_{2} \mathrm{O}_{3}$ hydrotalcite-derived catalysts. J. Catal. 2004, 228, 56-65. [CrossRef]

37. Yaripour, F.; Baghaei, F.; Schmidt, I.; Perregaard, J. Catalytic dehydration of methanol to dimethyl ether (DME) over solid-acid catalysts. Catal. Commun. 2005, 6, 147-152. [CrossRef] 